\title{
Supplementing $\alpha$-Linolenic acid in the in vitro maturation media improves nuclear maturation rate of oocytes and early embryonic development in the Nili Ravi buffalo
}

\author{
Asima Azam', Qaisar Shahzad ${ }^{2}$, Asma-Ul-Husna', Saima Qadeer ${ }^{3}$, Rabea Ejaz ${ }^{4}$, Ali A. Fouladi-Nashta ${ }^{5}$, \\ Muhammad Khalid ${ }^{5}$, Nemat Ullah ${ }^{6}$, Tasneem Akhtar ${ }^{2}$, Shamim Akhter ${ }^{1,7}$ \\ ${ }^{1}$ Animal Physiology Laboratory, Department of Zoology, Pir Mehr Ali Shah-Arid Agriculture University, Rawalpindi-46300, \\ Pakistan. \\ ${ }^{2}$ Buffalo Research Institute Pattoki, Kasur, Lahore-54000, Pakistan. \\ ${ }^{3}$ Department of Biological Sciences, University of Sargodha-Mianwali Campus-42200, Pakistan. \\ ${ }^{4}$ Department of Zoology, Shaheed Benazir Bhutto Women University Peshawar - 25000, Pakistan. \\ ${ }^{5}$ Reproduction, Genes and Development Research Group, The Royal Veterinary College, Hawkshead Lane, Hatfield, Herts AL9 \\ 7TA, UK. \\ ${ }^{6}$ Department of Animal Reproduction, Riphah International University, Lahore-54000 Pakistan
}

\begin{abstract}
The present study was conducted to investigate the effect of omega-3 poly unsaturated fatty acid (PUFA), $\alpha$-linolenic acid (ALA; 18:3 n-3) on the in vitro maturation (IVM) of buffalo oocytes and subsequent embryonic development. Buffalo cumulusoocyte complexes $(\mathrm{COCs} ; \mathrm{n}=2282)$ were in vitro matured in TCM-199 $(0.6 \%$ fatty acid free bovine serum albumin, 0.02 Units $/ \mathrm{ml} \mathrm{FSH,} 1 \mu \mathrm{g} / \mathrm{ml} 17-\beta$-estradiol, $10 \mu \mathrm{g} / \mathrm{ml}$ epidermal growth factor, $50 \mu \mathrm{g} / \mathrm{ml}$ gentamicin) supplemented with 0 (control), 25, 50, 100, 150 or $300 \mu \mathrm{m}$ ALA under an atmosphere of $5 \% \mathrm{CO}_{2}$ in air at $38.5^{\circ} \mathrm{C}$ for $22-24 \mathrm{~h}$. The matured oocytes were then fertilized in Tyrode's Albumin Lactate Pyruvate (TALP) medium and cultured in synthetic oviductal fluid (SOF) medium. Concentrations up to $100 \mu \mathrm{m}$ ALA improves $(\mathrm{P} \leq 0.05)$ the cumulus expansion compared to control. Higher percentage of oocytes reaching MII stage was observed at $50 \mu \mathrm{m}$ and $100 \mu \mathrm{m}$ of ALA compared to control $(\mathrm{P} \leq 0.05)$. Concentrations of 150 and $300 \mu \mathrm{m}$ ALA were detrimental both for cumulus expansion and nuclear maturation rate of buffalo oocytes. Moreover, supplementation with $100 \mu \mathrm{m}$ ALA improved $(\mathrm{P} \leq 0.05)$ cleavage rate compared to control and treatment with 50 and $100 \mu \mathrm{m}$ ALA yielded significantly higher morulae compared to control. The results of present study indicate that the supplementation with $100 \mu \mathrm{m}$ ALA to the IVM medium improves nuclear maturation rate of buffalo oocytes and subsequent early embryonic development.
\end{abstract}

Keywords: $\alpha$-linolenic acid, buffalo, embryonic development, nuclear maturation, omega-3 PUFAs.

\section{Introduction}

The Nili-Ravi buffalo is considered to be one of the best milk producers among other breeds of buffaloes in the world (Warriach et al., 2008). Although, this breed has the potential of producing more than $5000 \mathrm{~L}$ of milk/lactation (Bilal et al., 2006), the average milk yield is quite low, which raises the opportunities of genetic improvement through assisted reproductive technologies like artificial insemination, and multiple ovulation and embryo transfer (MOET).
However, the implementation of these technologies is hampered due to some inherent reproductive problems in buffalo such as fewer primordial follicles, which results in smaller number of recruitable follicles, high level of atresia, poor estrus behavior detection and a poor response to superovulation protocols (Madan, 1990). Recently, the emphasis has now been shifted towards the in vitro production (IVP) of buffalo embryos (Hansen, 2006) utilizing germ plasm of both male and female animals simultaneously (Barakat et al., 2012).

In vitro maturation (IVM) is a key step during which oocytes undergo all the necessary changes required for successful fertilization and further embryonic development (Wang et al., 1997). Therefore, the maturation medium is crucial, not only for the maturation of oocyte itself but also for its further competence after IVF (Bavister et al., 1992; Kharche et al., 2006). Previously, several studies have evaluated different types of media (Totey et al., 1993; Abdoon et al., 2001; Zicarelli et al., 2003), and its supplements including different sources of protein (Chauhan et al., 1998), hormones (Totey et al., 1993), thiol compounds (Zicarelli et al., 2005; Gasparrini et al., 2006), growth factors (Purohit et al., 2005) and antioxidants (Ullah et al., 2006) for in vitro maturation of buffalo oocytes with variable success rates and blastocyst production rate of no more than $10-20 \%$ (Kumar and Anand, 2012) which is relatively lower when compared to $30-40 \%$ blastocyst production rate in cattle (Rizos et al., 2008).

Fatty acids are essential for numerous physiological functions (Wathes et al., 2007), such as membrane biosynthesis (Sturmey et al., 2009), signal transduction and gene expression (Sampath and Ntambi, 2005). They also provide a potent energy source and prevent the lipotoxic effects result in from increased cellular contents of saturated fatty acids through lipid storage and $\beta$-oxidation (Dunning et al., 2014). Fatty acids are also precursors for prostaglandins and progesterone synthesis and therefore play an important role in the regulation of normal reproductive function (Abayasekara and Wathes, 1999; Mattos et al., 2000). Polyunsaturated fatty acids (PUFAs) play a significant role in increasing the number (Lucy et al., 1991) and size of ovarian follicles (Zeron et al., 2002), level of LH (Lucy et al., 1991) and progesterone in follicular fluid 
(Ryan et al., 1992), oocyte quality (Zeron et al., 2002), regulation of ovulation, CL function(Abayasekara and Wathes, 1999; Mattos et al., 2000) and pregnancy rate (Bellows et al., 1999).

PUFAs must be provided by diet, since their in vivo synthesis is not possible due to absence of proper enzymes (Gurr et al., 2002). Change in the composition of dietary fatty acids not only modifies fatty acid composition in the blood plasma but also of the reproductive tissues including, follicular fluid, cumulus cells and the oocytes (Ferguson and Leese, 1999; Zeron et al., 2002; Bilby et al., 2006; Childs et al., 2008; Fouladi-Nashta et al., 2009; Wonnacott et al., 2010), which can directly influence the competence of oocytes for further development and/or fertility (Armstrong et al., 1990; Burke et al., 1997; Petit et al., 2001; Wonnacott et al., 2010). For instance, dietary fish oil supplementation has been shown to alter the specific n-3 and n- 6 fatty acids in follicular fluid, cumulus cells and oocytes in both beef heifers (Childs et al., 2008) and ewes (Zeron et al., 2002; Wonnacott et al., 2010). Such changes in the fatty acid profile may improve oocyte maturation, which is essential for successful fertilization and further embryo development (Marei et al., 2009) Fatty acids supplemented into IVM medium yielded positive effects on oocyte maturation, fertilization, and embryonic development in the rat (Khandoker and Tsujii, 1999), goat, sheep (Veshkini et al., 2015) and cattle (Kim et al., 2001).

Alpha-linolenic acid (ALA; C18:3) is the dietary precursor for the long-chain omega-3 PUFAs (Brenna et al., 2009). It plays an important role in folliculogenesis, developmental competence of oocyte (Moallem et al., 2013), fertilization rate and embryo quality (Thangavelu et al., 2007). As ALA is produced by the ovarian follicles and the amount of ALA increases as the ovarian follicles enlarge (Veshkini et al., 2015); a role of specific unsaturated fatty acids like ALA may be speculated in the oocyte maturation and/or follicular growth. In fact, ALA has been shown to improve the fertility rate in both cattle and sheep by improving folliculogenesis and fertilization rate in vivo (Moallem et al., 2013). When supplemented in the in vitro maturation medium it was reported to regulate the molecular mechanism leading to increased number of MII stage oocytes and improved their subsequent development into early embryos in both cattle (FouladiNashta et al., 2009; Marei et al., 2009) and sheep (Ghaffarilaleh et al., 2014). However, the role of ALA supplementation of IVM media for Nili Ravi buffalo oocytes has not been studied yet. In this study we hypothesized that the supplementation of ALA in IVM media improves the quality of in vitro matured buffalo oocytes and their subsequent development postfertilization. The main objective of the study was to evaluate the effects of ALA supplementation of the IVM media on the in vitro oocyte maturation and subsequent embryonic development in buffalo.

\section{Materials and Methods}

\section{Collection of oocytes from buffalo ovaries}

Buffalo ovaries $(n=2500)$ were collected from the local abattoir and within two hours of collection transferred to the laboratory in a thermos containing sterilized phosphate buffered saline (PBS) kept at 33$35^{\circ} \mathrm{C}$. Fresh PBS was used to wash the ovaries immediately after arrival. Sterile disposable plastic syringe $(10 \mathrm{ml})$ fitted with 18 gauge needle was used to aspire cumulus-oocyte complexes (COCs) from antral follicles (2-8 mm). Searching for COCs was done under stereomicroscope in PBS and was classified as grade A, $\mathrm{B}, \mathrm{C}$ and $\mathrm{D}$, on the basis of their cumulus investment and ooplasm homogeneity (Sabasthin et al., 2013). Grade A COCs had four or more than four compact cumulus layers with homogenous ooplasm, while grade $\mathrm{B}$ oocytes had two to three layers of compact cells with homogenous ooplasm. Grade C oocytes had only one layer of less compact cells with irregular ooplasm, while the oocytes having irregular dark ooplasm and highly expanded cumulus cells and denuded oocytes were considered as grade D (Sabasthin et al., 2013). COCs $(n=2282)$ with homogenous ooplasm and more than two compact layers of cumulus cells were selected for the experiments.

\section{In vitro maturation (IVM) of oocytes}

COCs were in vitro matured in $100 \mu 1$ drops covered with sterile mineral oil for $24 \mathrm{~h}$ at $38.5^{\circ} \mathrm{C}$ in $5 \%$ $\mathrm{CO}_{2}$ in air with $95 \%$ humidity. All the media and culture dishes were equilibrated at $38^{\circ} \mathrm{C}$ in $\mathrm{CO}_{2}$ incubator for at least 1-2 $\mathrm{h}$ before experiment.

\section{Assessment of cumulus cell expansion}

After $24 \mathrm{~h}$ of maturation, cumulus cell expansion was assessed by visual assessment using stereomicroscope as 1) not expanded (no expansion observed in cumulus cells), 2) partially expanded (expansion of outer layers of cumulus cells only), or 3) fully expanded (expansion of all layers of cumulus cells; Azam et al., 2017).

\section{Oocyte staining and determination of stage of nuclear maturation}

For determination of nuclear stage in meiosis, COCs were completely denuded. Denuded oocytes were washed twice in PBS and fixed overnight in acetoethanol. Oocytes were placed on a grease free glass slide and covered with a cover slip. Oocytes were slightly compressed onto the glass slide with a needle until drop containing oocytes touched the cover slip. The oocytes were then stained with $1 \%$ aceto-orcein and de-stained with aceto-glycerol as described by Azam et al. (2017). Oocyte's nuclear maturation was evaluated with a phase contrast microscope at $200 \mathrm{X}$ to $400 \mathrm{X}$ magnification.

Based on morphology, nuclear maturation was categorized as described by Azam et al. (2017). Oocyte nucleus with a nucleolus and filamentous chromatin is at germinal vesicle (GV) stage. Oocyte without nucleolus, nuclear membrane and shortening of chromosomes is at germinal vesicle breakdown (GVBD) stage. At MI stage chromosomes look as thick 
dots arranged at metaphase plate. The segregation of chromosomes start at anaphase-I and at Telophase-I, complete segregation of chromosomal sets occur. First polar body is released at M-II.

\section{In vitro fertilization (IVF) of oocytes}

Frozen semen was used for in vitro fertilization (IVF). Three $0.5 \mathrm{ml}$ straws of cryopreserved buffalo semen were thawed in water bath at $37^{\circ} \mathrm{C}$ for $30 \mathrm{sec}$. Thawed semen was placed in a $15 \mathrm{ml}$ conical tube. Spermatozoa with maximum motility were collected by swim up technique (Parrish et al., 1986). About $250 \mu 1$ of thawed semen was deposited at the bottom of four 15 $\mathrm{ml}$ tubes containing $3 \mathrm{ml}$ of pre warmed sperm wash medium (TALP: modified calcium-free Tyrode's Albumin Lactate Pyruvate with $6 \mathrm{mg} / \mathrm{ml} \mathrm{BSA} \mathrm{fraction-}$ V). Tubes were incubated at $45^{\circ}$ angle for $30 \mathrm{~min}$ Supernatant from each tube was removed and transferred into another $15 \mathrm{ml}$ conical tube and centrifuged at $1600 \mathrm{rpm}$ for $10 \mathrm{~min}$. The pellet obtained after centrifugation of supernatant was assessed for sperm motility, and concentration was determined in an improved Neubauer counting chamber. Subsequently, sperm suspention was resuspended in pre-warmed fertilization TALP (supplemented with $0.1 \mathrm{mM}$ hypotaurine, $\quad 0.2 \mathrm{mM}$ penicillamine, $\quad 0.01 \mathrm{mM}$ epinephrine, $10 \mu \mathrm{g} / \mathrm{ml}$ heparin) to a final concentration of $2 \times 10^{6}$ cells $\mathrm{ml}^{-1}$.

After $24 \mathrm{~h}$ of IVM, buffalo oocytes were washed in fertilization media and were placed in fertilization droplets $(5 \mathrm{COCs} / 50 \mu \mathrm{l}$ droplet) of pre warmed fertilization media under mineral oil. Oocytes and spermatozoa were co-incubated for $20 \mathrm{~h}$ at $38.5^{\circ} \mathrm{C}$ under $5 \% \mathrm{CO}_{2}$ with maximum humidity (Gasparrini et al., 2008). The day of fertilization was defined as day 0 .

\section{In vitro culture (IVC) of embryos}

Following fertilization, presumptive zygotes were denuded by vigorous pipetting in PBS and transferred to $25 \mu \mathrm{l}$ drops containing IVC media (SOF) supplemented with BME, MEM and $5 \%$ fetal calf serum (FCS). Embryo culture was performed at $38.5^{\circ} \mathrm{C}$ in a humidified incubator with $5 \% \mathrm{CO}_{2}$ in air. On day 2 the cleavage rate (number of oocytes cleaved/total COCs incubated $\times 100$ ) was evaluated. Further developmental stages ( $4-8$ cell stage, $>8$ cell stage and morula) were evaluated and recorded every other day.

\section{Experimental design}

Linolenic acid (ALA; Stock solution in DMSO) was added at different levels $(0 \mu \mathrm{m}$ (control), $25,50,100,150,300 \mu \mathrm{m})$ to the maturation medium (TCM-199) supplemented with $0.6 \%$ fatty acid freebovine serum albumin (FAF-BSA), $0.02 \mathrm{IU} / \mathrm{ml} \mathrm{FSH,} 1$ $\mu \mathrm{g} / \mathrm{ml}$ estradiol-17 $\beta$ (E2), $10 \mu \mathrm{g} / \mathrm{mL}$ epidermal growth factor and $50 \mu \mathrm{g} / \mathrm{ml}$ gentamicin.

\section{Experiment 1}

Oocytes (1200) were randomly allocated to the experimental groups as described: 1) $0 \mu \mathrm{m}$ ALA (control); 2) $25 \mu \mathrm{m} \operatorname{ALA}(25)$; 3) $50 \mu \mathrm{m} \operatorname{ALA}(50)$; 4) $100 \mu \mathrm{m}$ ALA (100); 5) $150 \mu \mathrm{m}$ ALA (150); or 6) $300 \mu \mathrm{m}$ ALA (300). The experiment was replicated for seven times. Cumulus cells expansion and nuclear maturation status of oocytes after $24 \mathrm{~h}$ of IVM were evaluated.

\section{Experiment 2}

Oocytes (1082) were matured as in the experiment 1. Matured oocytes were fertilized and cultured. The experiment was replicated seven times. Embryonic development was assessed as cleaved, 4-8 cell stage, $>8$ cell stage and morula formation.

\section{Statistical analysis}

The data on the effect of different doses of ALA on COCs expansion, MII stage, cleavage rate and developmental stages ( 2 cell stage, $4-8$ cell stage, $>8$ cell stage and morula) were analyzed by one-way analysis of variance (ANOVA) after square root transformation $(\mathrm{Y}=\sqrt{\mathrm{X}}+0.5)$ and presented as Mean \pm SEM. Duncan's multiple range test (DMRT) was used to compare the treatment means. Results were considered significant at $\mathrm{P}<0.05$.

\section{Results}

\section{Experiment 1}

The data on the effect of ALA supplementation of maturation media on cumulus expansion are shown in Fig. 1 and 2. The addition of $25 \mu \mathrm{m}$ ALA in maturation media did not show improvement $(\mathrm{P}>0.05)$ in cumulus expansion compared to control. However, supplementation with 50 and $100 \mu \mathrm{m}$ ALA resulted in increased rate of cumulus expansion $(\mathrm{P} \leq 0.05)$ compared to control. The higher levels of ALA, i.e., 150 and $300 \mu \mathrm{m}$ resulted in significant decrease $(\mathrm{P}<0.05)$ in expansion of cumulus cells compared to other groups (Fig. 1 and 2).

Data of the effects of ALA supplementation in maturation media on percentage of oocytes at different stages of nuclear maturation are shown in Fig. 3. The higher percentage of oocytes reaching MII stage $(\mathrm{P} \leq 0.05)$ was observed with $50 \mu \mathrm{m}$ ALA $(67.0 \%$ $\pm 2.2)$ compared to control $(57.4 \% \pm 2.5)$ and $25 \mu \mathrm{m}$ ALA $(60.3 \% \pm 1.9)$ in IVM medium. Further improvement $(\mathrm{P} \leq 0.05)$ was observed with $100 \mu \mathrm{m}$ ALA $(76.3 \% \pm 2.5)$. The higher concentrations of ALA i.e., $150 \mu \mathrm{m}(51.3 \% \pm 1.8)$ and $300 \mu \mathrm{m}(29.8 \% \pm 2.3)$ resulted in a dose dependent decrease in percentage of oocytes reaching MII stage compared to $100 \mu \mathrm{m}$ ALA. The percentage of oocytes remaining at GVBD and MI stage were recorded higher in $300 \mu \mathrm{m}$ ALA $(26.2 \% \pm 2.2$ and $39.1 \% \pm 1.4)$ compared to control $(17.7 \% \pm 3.1$ and $20.7 \% \pm 2.4$ ), respectively. Percentage of degenerative oocytes was higher $(\mathrm{P}<0.05)$ with $300 \mu \mathrm{m}$ ALA $(4.9 \%$ \pm 2.5 ) compared to control, $25 \mu \mathrm{m}$ ALA and $150 \mu \mathrm{m}$ ALA $(1.9 \% \pm 1.2,1.8 \% \pm 1.2,1.0 \% \pm 1.0)$ respectively. No degenerative oocytes were observed with $50 \mu \mathrm{m}$ ALA and $100 \mu \mathrm{m}$ ALA. 


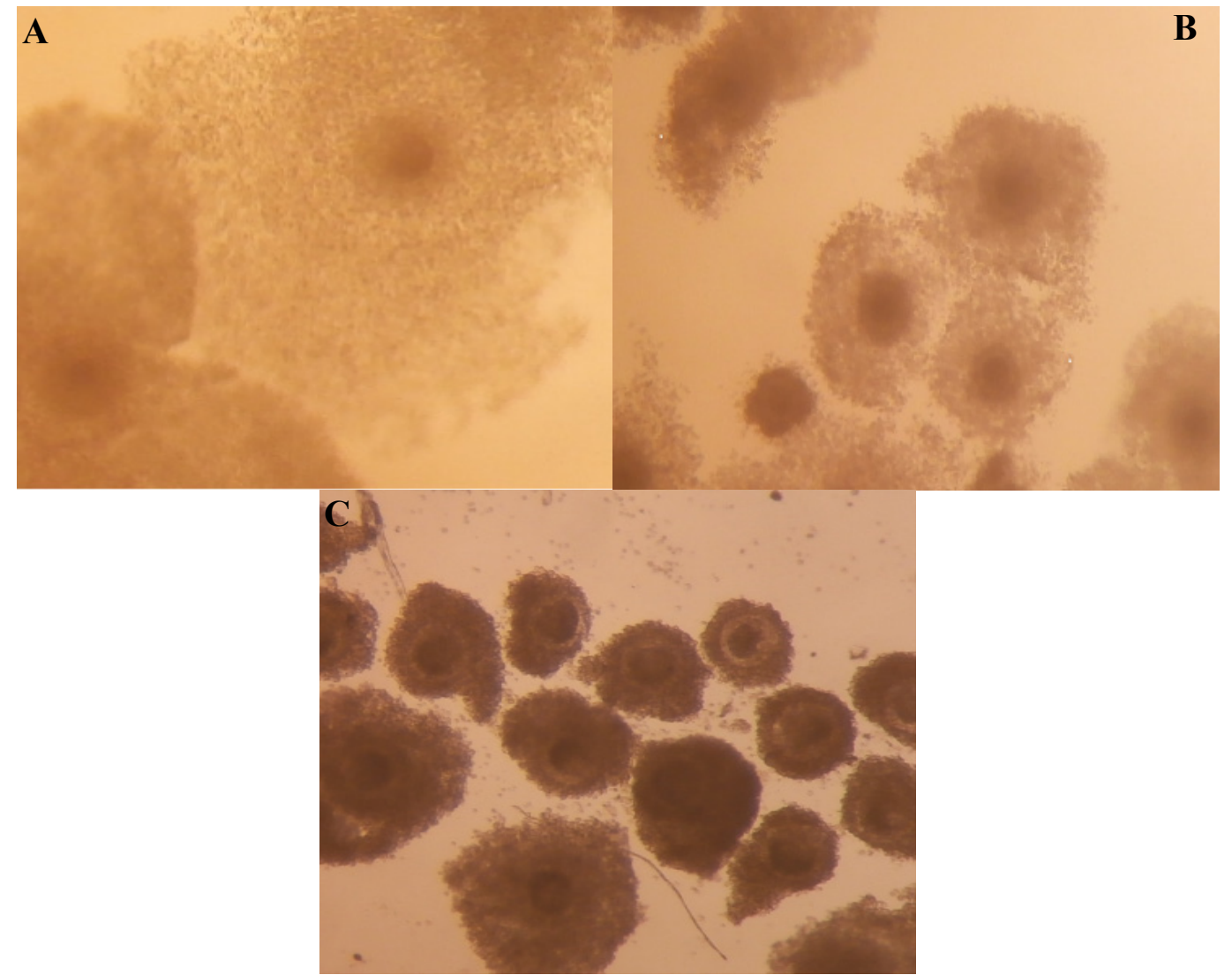

Figure 1. Representative pictures of COCs (A: fully expanded, B: partially expanded, C: not expanded) after $24 \mathrm{~h}$ of maturation.



Figure 2. Cumulus expansion rate of buffalo COCs after $24 \mathrm{~h}$ of maturation in IVM medium supplemented with different concentrations of ALA. Data are shown as Mean percentage \pm SEM. Bars with different superscripts differ significantly $(\mathrm{P}<0.05)$. 0 (Control), 25 (supplementation with $25 \mu \mathrm{m}$ ALA in the maturation media), 50 (supplementation with $50 \mu \mathrm{m}$ ALA in the maturation media), 100 (supplementation with $100 \mu \mathrm{m}$ ALA in the maturation media), 150 (supplementation with $150 \mu \mathrm{m}$ ALA in the maturation media), 300 (supplementation with $300 \mu \mathrm{m}$ ALA in the maturation media). 


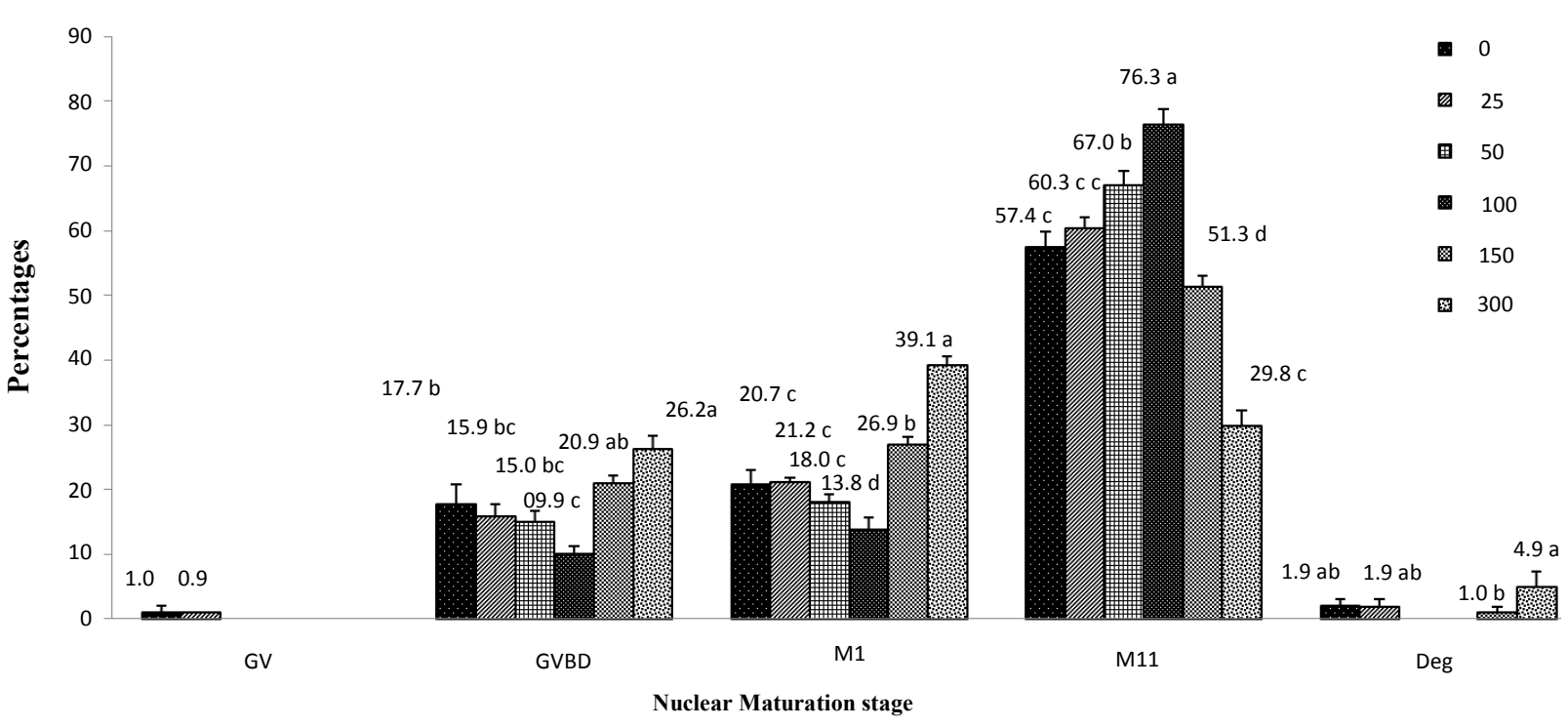

Figure 3. Nuclear maturation of buffalo oocytes after $24 \mathrm{~h}$ of maturation in IVM medium supplemented with different concentrations of ALA. Data are shown as Mean percentage \pm SEM. Bars with different superscripts differ significantly $(\mathrm{P}<0.05)$. GV: germinal vesicle, GVBD: germinal vesicle breakdown, MI: metaphase I, MII: metaphase II, Deg: degenerated.

\section{Experiment 2}

Data on the effect of ALA supplementation on percentage of cleaved, $4-8$ cells, $>8$ cells and morula are presented in Table 1. Supplementation with 25,50 and $150 \mu \mathrm{m}$ ALA (49.7 to $56.9 \%)$ did not improve (P > 0.05) the cleavage rate compared to the controls $(50.4 \% \pm$ 2.0). The addition of $100 \mu \mathrm{m}$ ALA $(57.8 \% \pm 1.0)$ raised $(\mathrm{P}<0.05)$ the cleavage rate compared to the controls $(50.4 \% \pm 2.0)$ and $150 \mu \mathrm{m}$ ALA $(49.7 \% \pm 2.8)$, but did not do so when compared to $25(51.1 \% \pm 2.5)$ and $50 \mu \mathrm{m}$ ALA $(56.9 \% \pm 2.0)$. A significant decrease $(\mathrm{P}<0.05)$ in cleavage rate was recorded when maturation media was supplemented with $300 \mu \mathrm{m}$ ALA $(21.0 \% \pm 2.5)$.

Embryos reaching 4-8 cell stage were higher $(\mathrm{P} \leq 0.05)$ when the oocytes were matured in the presence of ALA at $100 \mu \mathrm{m}(47.0 \% \pm 2.9)$ compared to control $(34.0 \% \pm 1.1)$ and to $25 \mu \mathrm{m}$ ALA $(36.6 \% \pm 3.8)$. At $50 \mu \mathrm{m}$ ALA $(42.3 \% \pm 1.5)$ embryos developed up to $4-8$ cell stage differ significantly $(\mathrm{P}<0.05)$ with control and to $150 \mu \mathrm{m}$ ALA $(31.2 \% \pm 0.8)$, while did not differ
$(\mathrm{P}>0.05)$ from 25 and $100 \mu \mathrm{m}$. The higher concentration used in this study, $300 \mu \mathrm{m}(14.3 \% \pm 1.8)$ resulted in the worst decrease $(\mathrm{P} \leq 0.05)$ on number of 4-8 cell embryos.

Recorded number of embryos that reached more than 8 cell stage was higher $(\mathrm{P} \leq 0.05)$ when the oocytes were matured in media supplemented with $100 \mu \mathrm{m}$ ALA $(38.0 \% \pm 2.2)$ followed by $50 \mu \mathrm{m}$ ALA $(31.1 \% \pm 1.6)$ and by control $(22.2 \% \pm 2.9)$ and $25 \mu \mathrm{m}$ ALA $(23.1 \% \pm$ 2.4). The increase in ALA supplementation up to 150 $\mu \mathrm{m}(14.4 \% \pm 1.8)$ and $300 \mu \mathrm{m}(1.2 \% \pm 1.2)$ compromised $(\mathrm{P} \leq 0.05)$ the embryo development to $>8$ cell embryos compared to other groups.

The percentage of morulae was increased $(\mathrm{P}<$ $0.05)$ with the supplementation of $50 \mu \mathrm{m}$ ALA $(17.8 \% \pm$ $2.3)$ and $100 \mu \mathrm{m}(21.0 \% \pm 2.6)$ compared to control $(11.2 \% \pm 2.6)$ and $25 \mu \mathrm{m}$ ALA $(12.1 \% \pm 2.1)$, while 150 $\mu \mathrm{m} \operatorname{ALA}(7.8 \% \pm 0.2)$ in maturation media resulted in decreased $(\mathrm{P} \leq 0.05)$ number of morulae. None of the embryos developed to morula stage $(\mathrm{P}>0.0)$ when the oocytes were matured with $300 \mu \mathrm{m}$ ALA.

Table 1. Effect of supplementation of IVM medium with different concentrations of ALA on the cleavage rate and subsequent embryo development of buffalo oocytes after in vitro fertilization.

\begin{tabular}{lccccc}
\hline \multirow{2}{*}{ Treatments } & \multicolumn{5}{c}{ Developmental stages (Mean percentage \pm SEM) } \\
\cline { 2 - 6 } & $\begin{array}{c}\text { No. of } \\
\text { COCs }\end{array}$ & $\begin{array}{c}\text { Cleavage } \\
\% \pm \text { SEM }\end{array}$ & $\begin{array}{c}-8 \text { cell embryos } \\
\% \pm \text { SEM }\end{array}$ & $\begin{array}{c}>8 \text { cell embryos } \\
\% \pm \text { SEM }\end{array}$ & $\begin{array}{c}\text { Morulae } \\
\% \pm \text { SEM }\end{array}$ \\
\hline 0 & 182 & $92(50.4 \pm 2.0)^{\mathrm{b}}$ & $62(34.0 \pm 1.1)^{\mathrm{c}}$ & $40(22.2 \pm 2.9)^{\mathrm{c}}$ & $20(11.2 \pm 2.6)^{\mathrm{b}}$ \\
25 & 180 & $92(51.1 \pm 2.5)^{\mathrm{ab}}$ & $66(36.6 \pm 3.8)^{\mathrm{bc}}$ & $42(23.1 \pm 2.4)^{\mathrm{c}}$ & $22(12.1 \pm 2.1)^{\mathrm{b}}$ \\
50 & 180 & $102(56.9 \pm 2.0)^{\mathrm{ab}}$ & $76(42.3 \pm 1.5)^{\mathrm{ab}}$ & $56(31.1 \pm 1.6)^{\mathrm{b}}$ & $32(17.8 \pm 2.3)^{\mathrm{a}}$ \\
100 & 180 & $104(57.8 \pm 1.0)^{\mathrm{a}}$ & $84(47.0 \pm 2.9)^{\mathrm{a}}$ & $68(38.0 \pm 2.2)^{\mathrm{a}}$ & $38(21.0 \pm 2.6)^{\mathrm{a}}$ \\
150 & 180 & $90(49.7 \pm 2.8)^{\mathrm{b}}$ & $56(31.2 \pm 0.8)^{\mathrm{c}}$ & $26(14.4 \pm 1.8)^{\mathrm{d}}$ & $14(7.8 \pm 0.2)^{\mathrm{b}}$ \\
300 & 180 & $38(21.0 \pm 2.5)^{\mathrm{c}}$ & $26(14.3 \pm 1.8)^{\mathrm{d}}$ & $2(1.2 \pm 1.2)^{\mathrm{e}}$ & $0(0.0 \pm 0.0)^{\mathrm{c}}$ \\
\hline
\end{tabular}

Data were collected in seven independent replicates. ${ }^{\mathrm{a}, \mathrm{b}, \mathrm{c}, \mathrm{d}, \mathrm{e}}$ The values with different superscripts in the same column differ significantly $(\mathrm{P}<0.05)$. 0 (Control), 25 (supplementation with $25 \mu \mathrm{M}$ ALA in the maturation media), 50 (supplementation with $50 \mu \mathrm{m}$ ALA in the maturation media), 100 (supplementation with $100 \mu \mathrm{m}$ ALA in the maturation media), 150 (supplementation with $150 \mu \mathrm{m}$ ALA in the maturation media), 300 (supplementation with $300 \mu \mathrm{m}$ ALA in the maturation media). 


\section{Discussion}

The fatty acid content of developing oocytes changes depending on the environment in which they develop (Wakefield et al., 2008). Changing the microenvironment of oocyte also changes intra-cytoplasmic concentration of lipids. Therefore, PUFAs in the microenvironment may replace saturated FAs in the oocyte cytoplasm and make the oocyte membrane comparatively more permeable for sperm entry and increase fertilization rate and developmental competence of the oocyte. Present study shows that supplementation of maturation media with $100 \mu \mathrm{m}$ ALA increased the number of fully expanded oocytes. Supporting our current findings, a previous study (Marei et al., 2009) demonstrated that supplementation of maturation medium with ALA at a concentration of lower than $100 \mu \mathrm{m}$ had no adverse effect on cumulus cell expansion in cattle. The deleterious effect of ALA at a concentration of 150 and $300 \mu \mathrm{m}$ in the present study is consistent with the previous studies (CoyralCastel et al., 2010; Ghaffarilaleh et al., 2014; Veshkini et al., 2015) that reported decreased viability of granulosa cells with higher concentration of ALA after $24 \mathrm{~h}$ of maturation. In the present study, high levels of ALA in maturation medium might have been outside the tolerance threshold of the cells, exerted toxic effect leading to a reduction in cell viability (Andrade et al., 2005).

Cumulus cells are important for keeping the oocytes under meiotic arrest, inducing meiotic resumption and supporting cytoplasmic maturation These functions have been attributed to their gap junctions and their specific metabolizing capabilities (Tanghe et al., 2002). It is anticipated that cumulus cells mediate signals and regulate the synthesis of important cytoplasmic factors which support nuclear maturation (Albertini et al., 2001). However, it is not fully understood that expansion of cumulus cells is prerequisite for nuclear maturation or both processes are not inter-related. It has been reported in the ovine that cumulus cell expansion is prerequisite for nuclear maturation (Amini et al., 2016), at the same time no such connection has also been reported in the bovine (Marei et al., 2010; Khalil et al., 2013).

Meiotic competence of oocytes determines the developmental capacity for subsequent embryo development. In the present study, supplementation of maturation medium with $100 \mu \mathrm{m}$ ALA increased the MII rate of buffalo oocytes. High doses of ALA in IVM medium inhibited maturation progression, manifested by high percentage of oocytes arrested at GVBD or MI stage and a concomitant decrease in percentage of oocytes that completed second meiotic division metaphase. Our results are in agreement with the results of Veshkini et al. (2015) who reported improved nuclear maturation in sheep oocytes at $100 \mu \mathrm{m}$ ALA in maturation medium. The positive effect of ALA on oocyte's meiotic competence may be mediated directly by improvement of cytoplasmic maturation via the mitogen-activated protein kinase pathway and indirectly through PGE2 synthesis (Marei et al., 2009). The PGE2 is a key paracrine and/or autocrine regulator of cumulus cell functions and has been proposed to play a major role in oocyte nuclear maturation (Elvin et al., 2000). An elevated concentration of PGE2 positively stimulated the extent of cumulus expansion and nuclear maturation by enhancing the phosphorylation of MAPK1 and MAPK2 in both oocytes and cumulus cells through the elevation of cAMP levels (Marei et al., 2009).

In addition to the positive effects observed on cumulus expansion and oocyte nuclear maturation, improvement in all developmental stages of buffalo embryos was observed when oocytes were matured in the presence of $50-100 \mu \mathrm{m}$ ALA in the maturation media. Similar to the findings of our study, an increased rate of embryonic development has been observed with supplementation of ALA in maturation media in the bovine (Marei et al., 2009), sheep (Ghaffarilaleh et al., 2014) and goat oocytes (Veshkini et al., 2015). Provision of ALA in maturation media might have improved the cellular processes during different phases of maturation, which in turn influenced the developmental competence of subsequent embryos (Krisher and Bavister, 1998). In another study on the bovine, addition of ALA to the culture medium did not improve the cleavage and blastocyst rates; however, the viability of the embryos was influenced in a positive manner by the presence of ALA in culture medium (Al Darwich et al., 2010). It is relevant to mention that the improvement in embryo development rate in present study can only be attributed to supplementation of ALA during oocyte maturation as maturation medium was serum free and there was no supplementation during in vitro embryo culture. Thesefinding s suggest that ALA might have been more important to the oocytes if added to the maturation medium rather than to the culture medium after fertilization.

In the present study, ALA at higher concentrations (300 $\mu \mathrm{m}$ ALA) resulted in reduced number of cleaved embryos and no morula stage embryos. Since PUFAs are more susceptible to peroxidation than monounsaturated and saturated fatty acids, supplementation at higher levels might have increased the oxidative stress (Song et al., 2000; Gladine et al., 2007). Higher levels of ALA might have disturbed the balance of unsaturated and saturated fatty acids, so it might be the ratio of saturated vs unsaturated FAs that is more critical in the oocyte's microenvironment rather than a certain concentration of the unsaturated FAs per se. Therefore, one may speculate that the higher concentrations of ALA in our study might have generated oxidative stress after oxidative phosphorylation of ALA (Wakefield et al., 2008) which might have compromised the developmental competence of these oocytes and be responsible for the observed reduction of embryonic growth. Further studies may be suggested to investigate whether antioxidant supplementation of ALA-supplemented IVM medium could abrogate negative effects as observed for higher concentrations of ALA. In conclusion, the results of the present study have shown that supplementation of in vitro maturation media with 
ALA at $100 \mu \mathrm{m}$ improves the in vitro maturation of buffalo oocytes that in turn improves early embryonic development.

\section{Acknowledgments}

The authors thank Higher Education Commission, Pakistan, for financial support under $\mathrm{PhD}$ 5000 indigenous Fellowship Program.

\section{References}

Abayasekara DR, Wathes DC. 1999. Effects of altering dietary fatty acid composition on prostaglandin synthesis and fertility. Prostaglandins Leukot Essent Fatty Acids, 61:275-287.

Abdoon ASS, Kandil OM, Otoi T, Suzuki T. 2001. Influence of oocyte quality, culture media and gonadotropins on cleavage rate and development of in vitro fertilized buffalo embryos. Anim Reprod Sci, 65:215-223.

Al Darwich A, Perreau C, Petit MH, Papillier P, Dupont J, Guillaume D, Mermillod P, Guignot F 2010. Effect of PUFA on embryo cryoresistance, gene expression and AMPK alpha phosphorylation in IVFderived bovine embryos. Prostaglandins Other Lipid Mediat, 93:30-36.

Albertini DF, Combelles CM, Benecchi E, Carabatsos MJ. 2001. Cellular basis for paracrine regulation of ovarian follicle development Reproduction, 121:647-653.

Amini E, Asadpour R, Roshangar L, Jafari-Joozani R. 2016. Effect of linoleic acid supplementation on in vitro maturation, embryo development and apoptotic related gene expression in ovine. Int J Reprod Biomed, 14:255-262.

Andrade LN, de Lima TM, Curi R, Castrucci AM. 2005. Toxicity of fatty acids on murine and human melanoma cell lines. Toxicol In Vitro, 19:553-560.

Armstrong JD, Goodall EA, Gordon FJ, Rice DA, McCaughey WJ. 1990. The effects of levels of concentrate offered and inclusion of maize gluten or fish meal in the concentrate on reproductive performance and blood parameter of dairy cows. Anim Prod, 50:1-10. Azam A, Husna AU, Shahzad Q, Akhtar T, Haq E, Ullah N, Akhter S. 2017. Efficiency of fatty acid-free defined system for in vitro maturation of buffalo oocytes. J Anim Plant Sci, 27:112-118.

Barakat IAH, El-Ashmaoui HM, Barkawi A, Kandeal SA, EL-Nahass E. 2012. Ultra-structural study of Egyptian buffalo oocytes before and after in vitro maturation. Afr J Biotechnol, 11:7592-7602.

Bavister BD, Rose-Hellekant TA, Pinnyomminter T. 1992. Development of in vitro and matured in vitro fertilized bovine embryos into morula and blastocyst in defined culture media. Theriogenology, 37:127-146.

Bellows RA, Simms DD, Grings EE, Phelps DA, Bellows SE, Bellows NR, Short RE, Funston RN, Geary TW. 1999. Effects of feeding supplemental fat during gestation on reproduction in primiparous beef heifers. J Anim Sci, 77(suppl.1):236. (abstract).

Bilal MQ, Suleman M, Raziq A. 2006. Buffalo: Black gold of Pakistan. Livest Res Rural Dev, 18:140-151. Bilby TR, Block J, Amaral BCD, Filho OS, Silvestre FT, Hansen PJ, Staples CR, Thatcher WW. 2006. Effects of dietary unsaturated fatty acids on oocyte quality and follicular development in lactating dairy cows in summer. J Dairy Sci, 89:3891-3903.

Brenna JT, Salem NJ, Sinclair AJ, Cunnane SC. 2009. Alpha-linolenic acid supplementation and conversion to n-3 long-chain polyunsaturated fatty acids in humans. Prostaglandins Leukot Essent Fatty Acids, 80:85-91.

Burke JM, Staples CR, Risco CA, Sota RLDL, Thatcher WW. 1997. Effect of ruminant grade menhaden fish meal on reproductive performance of lactating dairy cows. J Dairy Sci, 80:3386-3398.

Chauhan MS, Singla SK, Palta P, Manik RS, Madan ML. 1998. In vitro maturation and fertilization, and subsequent development of buffalo (Bubalus bubalis) embryos: effects of oocyte quality and type of serum. Reprod Fertil Dev, 10:173-177.

Childs S, Hennessy AA, Sreenan JM, Wathes DC, Cheng Z, Stanton C, Diskin MG, Kenny DA. 2008. Effect of level of dietary n-3 polyunsaturated fatty acid supplementation on systemic and tissue fatty acid concentrations and on selected reproductive variables in cattle. Theriogenology, 70:595-611.

Coyral-Castel S, Rame C, Fatet A, Dupont J. 2010. Effects of unsaturated fatty acids on progesterone secretion and selected protein kinases in goat granulosa cells. Domest Anim Endocrinol, 38:272-283

Dunning KR, Russell DL, Robker RL. 2014. Lipids and oocyte developmental competence: the role of fatty acids and $\beta$-oxidation. Reproduction, 148:15-27.

Elvin JA, Yan C, Matzuk MM. 2000. Growth differentiation factor-9 stimulates progesterone synthesis in granulosa cells via a prostaglandin E2/EP2 receptor pathway. Proc Natl Acad Sci USA, 97:1028810293

Ferguson EM, Leese HJB. 1999. Triglyceride content of bovine oocytes and early embryos. J Reprod Fertil, 116:373-378.

Fouladi-Nashta AA, Wonnacott KE, Gutierrez CG, Gong JG, Sinclair KD, Garnsworthy PC, Webb R. 2009. Oocyte quality in lactating dairy cows fed on high levels of $\mathrm{n}-3$ and $\mathrm{n}-6$ fatty acids. Reproduction, 138:771-781.

Gasparrini B, Boccia L, Marchandise J, Palo RD, George F, Donnay I, Zicarelli L. 2006. Enrichment of in vitro maturation medium for buffalo (Bubalus bubalis) oocytes with Thiol compounds: effects of cystine on glutathione synthesis and embryo development. Theriogenology, 65:275-287.

Gasparrini B, Rosa AD, Attanasio L, Boccia L, Palo RD, Campanile G, Zicarelli L. 2008. Influence of the duration of in vitro maturation and gamete coincubation on the efficiency of in vitro embryo development in Italian Mediterranean buffalo (Bubalus bubalis). Anim Reprod Sci, 105:354-364.

Ghaffarilaleh V, Fouladi-Nashta A, Paramio M. 2014. Effect of $\alpha$-linolenic acid on oocyte maturation and embryo development of pre-pubertal sheep oocytes. Theriogenology, 82:686-696. 
Gladine C, Morand C, Rock E, Gruffat D, Bauchart D, Durand D. 2007. The antioxidative effect of plant extracts rich in polyphenols differs between liver and muscle tissues in rats fed n-3 PUFA rich diets. Animal Feed Science and Technology, 139:257-272.

Gurr MI, Harwood JL, Frayn KN. 2002. Lipid Biochemistry: an introduction. 5th ed. Oxford, UK: Blackwell Science.

Hansen PJ. 2006. Realizing the promise of IVF in cattle, an overview. Theriogenology, 65:119-125.

Khalil WA, Marei WFA, Khalid M. 2013. Protective effects of antioxidants on linoleic acid-treated bovine oocytes during maturation and subsequent embryo development. Theriogenology, 80:161-823.

Khandoker MAM, Tsujii H. 1999. Effect of exogenous fatty acids on in vitro development of rat embryos. Asian Australas J Anim Sci, 12:169-173.

Kharche SD, Goel AK, Jindal SK, Sinha NK. 2006. In vitro maturation of caprine oocytes in different concentrations of estrous goat serum. Small Rumin Res, 64:186-189.

Kim JY, Kinoshita M, Ohnishi M, Fukui Y. 2001 Lipid and fatty acid analysis of fresh and frozen thawed immature and in vitro matured oocytes. Reproduction, 122:131-138

Krisher RL, Bavister BD. 1998. Responses of oocytes and embryos to the culture environment Theriogenology, 49:103-114.

Kumar D, Anand T. 2012. In vitro embryo production in buffalo: basic concepts. J Buffalo Sci, 1:50-54.

Lucy MC, Staples CR, Michel FM, Thatcher WW. 1991. Energy balance and size and number of ovarian follicles detected by ultrasonography in early postpartum dairy cows. J Dairy Sci, 74:473-482.

Madan ML. 1990. Conservation of germplasm through embryo transfer. In: Proceedings of the 13th International Dairy Congress, 1990, Montreal. Montreal, QC: IDF. pp. 302-314.

Marei WF, Wathes DC, Fouladi-Nashta AA. 2009. The effect of linolenic acid on bovine oocyte maturation and development. Biol Reprod, 81:1064-1072.

Marei WF, Wathes DC, Fouladi-Nashta AA. 2010 Impact of linoleic acid on bovine oocyte maturation and embryo development. Reproduction, 139:97-88.

Mattos R, Staples CR, Thatcher WW. 2000. Effects of dietary fatty acids on reproduction in ruminants. Rev Reprod, 5:38-45.

Moallem U, Shafran A, Zachut M, Dekel I, Portnick Y, Arieli A. 2013. Dietary a-linolenic acid from flaxseed oil improved folliculogenesis and IVF performance in dairy cows, similar to eicosapentaenoic and docosahexaenoic acids from fish oil. Reproduction, 146:603-614.

Parrish JJ, Susko-Parrish JL, Leibfreid-Rutledge ML, Crister ES, Eystone WH, First NL. 1986. Bovine in vitro fertilization with frozen-thawed semen. Theriogenology, 25:591-600.

Petit HV, Dewhurst RJ, Proulx JG, Khalid M, Haresign W, Twagiramungu H. 2001. Milk production, milk composition, and reproductive function of dairy cows fed different fats. Can J Anim Sci, 81:263-271.
Purohit GN, Brady MS, Sharma SS. 2005. Influence of EGF and IGF-1 on maturation and fertilization of buffalo cumulus oocyte complex in serum free media and their subsequent development in vitro. Anim Reprod Sci, 87:229-239.

Rizos D, Clemente M, Bermejo-Alvarez P, Fuente J de La, Lonergan P, Gutierrez-Adan A. 2008. Consequences of in vitro culture conditions on embryo development and quality. Reprod Domest Anim, 43:4450

Ryan DP, Spoon RA, Williams GL. 1992. Ovarian follicular characteristics, embryo recovery, and embryo viability in heifers fed high fat diets and treated with follicle-stimulating hormone. J Anim Sci, 70:3505-3513. Sabasthin A, Nandi S, Kumar VG, Gowda PSUS, Murthy VC. 2013. Effect of sera of normal cycling, pregnant and repeat breeding buffaloes (Bubalus bubalis) on in vitro maturation of buffalo, sheep and goat oocytes. Asian Pac J Reprod, 2:110-113.

Sampath H, Ntambi JM. 2005. Polyunsaturated fatty acid regulation of genes of lipid metabolism. Annu Rev Nutr, 25:317-340.

Song JH, Fujimoto K, Miyazawa, T. 2000. Polyunsaturated (n-3) fatty acids susceptible to peroxidation are increased in plasma and tissue lipids of rats fed docosahexaenoic acid-containing oils. J. Nutr, 130:3028-33.

Sturmey R, Reis A, Leese H, McEvoy T. 2009. Role of fatty acids in energy provision during oocyte maturation and early embryo development. Reprod Domest Anim, 44:50-58.

Tanghe S, Soom AV, Nauwynck H, Coryn M, DeKruif A. 2002. Minireview: functions of the cumulus ophorous during oocyte maturation, ovulation and fertilization. Mol Reprod Dev, 61:414-424.

Thangavelu G, Colazo MG, Ambrose DJ, Oba M, Okine EK, Dyck MK. 2007. Diets enriched in unsaturated fatty acids enhance early embryonic development in lactating Holstein cows. Theriogenology, 68:949-957.

Totey SM, Pawshe CH, Singh GP. 1993. In vitro maturation and fertilization of buffalo oocytes (Bubalus bubalis): efect of media, hormone and sera. Theriogenology, 39:1153-1171.

Ullah I, Jalali S, Shami SA, farooq K, Khan MI. 2006. Effect of 2-mercaptoethanol on Nili Ravi buffalo oocytes on in vitro maturation. J Anim Vet Adv, 5:380-385.

Veshkini A, Asadi H, Khadem AA, MohammadiSangcheshmeh A, Khazabi S, Aminafshar M, Deldar H, Soleimani M, Cinar MU. 2015. Effect of linolenic acid during in vitro maturation of ovine oocytes: embryonic developmental potential and mRNA abundances of genes involved in apoptosis. $J$ Assist Reprod Genet, 32:653-659.

Wakefield SL, Lane M, Schulz SJ, Hebart ML, Thompson JG, Mitchell M. 2008. Maternal supply of omega-3 polyunsaturated fatty acids alters mechanisms involved in oocyte and early embryo development in the mouse. Am J Physiol Endocrinol Metab, 294:425-434.

Wang WH, Hosoe M, Shioya Y. 1997. Induction of cortical granule exocytosis of pig oocytes by spermatozoa during meiotic maturation. J Reprod Fertil, 
109:247-255.

Warriach HM, Channa AA, Ahmad N. 2008. Effect of oestrus synchronization methods on oestrus behaviour, timing of ovulation and pregnancy rate during the breeding and low breeding season in NiliRavi buffaloes. Anim Reprod Sci, 107:62-67.

Wathes DC, Abayasekara DR, Aitken RJ. 2007. Polyunsaturated fatty acids in male and female reproduction. Biol Reprod, 77:190-201.

Wonnacott KE, Kwong WY, Hughes J, Salter AM, Lea RG, Garnsworthy PC, Sinclair KD. 2010. Dietary omega-3 and omega-6 polyunsaturated fatty acids affect the composition and development of sheep granulosa cells, oocytes and embryos. Reproduction,
139:57-69.

Zeron Y, Sklan D, Arav A. 2002. Effect of polyunsaturated fatty acid supplementation on biophysical parameters and chilling sensitivity of ewe oocytes. Mol Reprod Dev, 61:271-278.

Zicarelli L, Neglia G, di Brienza VC, Papaccio G, Esposito L, Gasparrini B. 2003. Buffalo (Bubalus bubalis) in vitro embryo production in two different defined culture media. Italian J Anim Sci, 1:136-138.

Zicarelli L, Donnay I, De Rosa A, Boccia L, Monaco E, Attanasio L, Gasparrini B. 2005. Use of thiol compounds during in vitro maturation of buffalo oocytes: effects on embryo development. Ital J Anim Sci, 4:304-306. 